\title{
Agrowisata Kampung Terih Sebagai Pengembangan Desa Pariwisata Di Batam
}

\author{
Syafruddin Rais ${ }^{1^{*}}$ \\ ${ }^{1}$ Politeknik Pariwisata Batam \\ *e-mail: rais@btp.ac.id
}

\begin{abstract}
Abstrak - Penelitian ini dilatarbelakangi oleh perilaku wisatawan dan masyarakat lokal pada agrowisata kampung terih sebagai pengembangan desa pariwisata di Batam. Studi ini bertujuan merumuskan model terbaik untuk mengembangkan wisata kampung terih di Batam. Model objek wisata yang diharapkan oleh pemeringkatan adalah motivasi yang kuat untuk mendorong wisatawan mengunjungi kampung terih adalah melatih fisik, mengunjungi tempat baru, memperkaya kecerdasan, istirahat dan menjauhkan diri dari stres. Pada aksesibilitas, para wisatawan menganggap bahwa jarak perjalanan kampung terih cukup jauh, dan sulit dijangkau dengan transportasi umum. Selain jarak yang cukup jauh, jalur yang harus dilalui ke kampung terih juga termasuk jalur sibuk. Hasil penelitian yang telah dilakukan menunjukkan bahwa kampung terih telah dikelola dengan baik yang terbukti dari keterlibatan masyarakat setempat (komunitas pariwisata), layanan panduan (link agen perjalanan). Transformasi ekonomi desa untuk mengunjungi kampung terih sangat kuat, pariwisata untuk mengunjungi kampung terih sedang, dan keberlanjutan kampung terih lemah.
\end{abstract}

Kata Kunci : perilaku wisatawan masyarakat lokal, objek wisata, fasilitas, aksesibilitas, komite pariwisata

\begin{abstract}
This research is motivated by the behavior of tourists and local people in the village agro tourism as the development of a tourism village in Batam. This study aims to formulate the best model for developing terih village tourism in Batam. The tourism object model expected by the ranking is a strong motivation to encourage tourists to visit the village, which is physical training, visiting new places, enriching intelligence, resting and staying away from stress. In terms of accessibility, tourists consider that the distance of the village trip is quite far, and is difficult to reach by public transportation. In addition to a considerable distance, the path that must be traversed to the village also includes a busy path. The results of the research that have been carried out show that the village has been well managed as evidenced by the involvement of the local community (tourism community), guidance services (travel agent links). The transformation of the village economy to visit the terih village is very strong, tourism to visit the terih village is moderate, and the sustainability of the terih village is weak.
\end{abstract}

Keywords : local tourist behavior, tourist attractions, tourism facilities, accessibility, tourism committee

This is an open access article distributed under the Creative Commons 4.0 Attribution License

\section{Pendahuluan}

Pengembangan pariwisata merupakan salah satu bentuk pembangunan sektor pariwisata yang sangat diperlukan dalam rangka meningkatkan daya tarik wisatawan untuk berkunjung. Pariwisata yang dikelola dengan baik juga akan menambah salah satu pemasukan Pendapatan Asli Daerah
(PAD) [1].

Karakteristik kampung terih dan tata nilai kehidupan masyarakat nya sangat memungkinkan untuk dikembangkan sebagai objek wisata di Batam. Pariwisata lainnya yang menjadi kebanggaan tersendiri bagi kota Batam adalah banyak nya wisata bawah laut sudah tersebar di daerah-daerah tersebut yang memiliki nilai ekonomis jika ini terus gencar di promosikan. 
Terih sejak 2 tahun terakhir mengharuskan untuk membahas tentang langkahlangkah pengembangan masa depan yang tepat untuk tujuan wisata ini, sehingga diperlukan suatu studi pengembangan pariwisata yang melibatkan masyarakat setempat, terutama masyarakat di sekitar Kampung Wisata Kampung Terih, yang besar nelayan. Data diperoleh dari penelitian kepustakaan [2].

Untuk mengetahui perkembangan wisatawan mancanegara dan domestik yang berkunjung ke desa Kampung Terih sebagai objek wisata yang ada di kota Batam guna untuk menikmati keindahan alamnya. Jenis penelitian yang digunakan adalah penelitian kualitatif dengan metode deskriptif. Dalam penelitian ini penulis mengumpulkan data primer dengan cara observasi langsung ke lokasi penelitian yang berada Kampung Terih, wawancara dengan pekerja dan wisatawan mancangera, dilengkapi dengan hasil rekaman, peneliti juga menggunakan sumber primer sebagai data pendukung yang meliputi dari foto foto dan dokumentasi dilapangan. Hasil penelitian ini menunjukan bahwa exsistensi objek wisata Kampung Terih terhadap wisatawan mancanegara dan domestik terus mengalami peningkatan lapangan pekerjaan dan pendapatan daerah kota Batam serta jumlah wisatawan yang berkunjung di desa kampung terih yang terdapat di kota Batam [4]; [5].

Hal ini terkait dengan meningkatnya pendapatan negara dari sektor pariwisata seyogia dapat mendukung pertumbuhan ekonomi suatu negara [14]. Dapat dimaknai pula oleh negara menjadi salah cadangan devisa keuangan negara yang memilki potensi besar dalam meningkatkan kualitas ekonomi di kota Batam. Pariwisata yaitu, mengembangkan peluang untuk menarik seseorang untuk berkunjung kesuatu tempat yang labih baik [14].

Desa Wisata Kampung Terih terletak di kawasan Nongsa Kota Batam, diresmikan pada 26 November 2017. Desa wisata terkenal dengan wisata instagrammablenya yang dipadukan dengan nuansa pantai putih berpasir dengan air laut yang jernih. Ada beberapa lokasi yang bagus dan akan meningkatkan daya kunjung wisatawan kota Batam. Dari dermaga terlihat kerlap-kerlip lampu perkotaan yang mendambah keindahan desa wisata kampung terih tersebut.

Selain terkenal dengan tempat wisata swafoto dan instrumentalnya, kampung tering juga terkenal sebagai salah satu destinasi wisata ekologi sebagai tempat penyelamatan penyu dan elang laut di Batam. Kampung Terih Batam dan didukung juga dengan menghadirkan pasar bakau yang menghadirkan konsep digital di desa wisata kampung terih Nongsa Batam. Sebagai salah satu bentuk apresiasi terhadap keindahan alam yang terdapat di Kota Batam [4]; [5]. Salah satu sasaran yang dilirik dalam pengembangan kawasan wisata desa Kampung Terih kedepannya adalah kawasan pengembangan masyarakat sebagai salah satu kegiatan pendukung di kawasan wisata desa.

Merujuk pada posisi kota Batam yang strategis, maka kebutuhan akan destinasi wisata seperti desa dibutuhkan untuk menarik para wisatawan lokal maupun mancanegara. Berdasarkan Garis-garis Besar Negara Haluan 1998 menyatakan pengembangan objek wisata yang dimaksudkan untuk pariwisata yang terbaik di kota Batam. Salah satu destinasi desa wisata adalah desa wisata Kampung Terih.

Tujuan pengembangan pariwisata di Batam adalah untuk mewujudkan keberlanjutan pariwisata berbasis budaya melayu. Batam ialah sebuah kota yang berbudaya melayu. Akar budaya itu terus dijaga oleh Pemerintah Kota Batam. Untuk itu, Pemko Batam mengajak masyarakat sekitar untuk menjaga kelestarian wisata di kota Batam. Salah satu visi pariwisata pengembangan di Batam adalah mengembangkan pariwisata kampung terih yang berbasis pada adat setempat yaitu melayu. Ini berarti bahwa pariwisata harus dikembangkan sesuai dengan prinsip-prinsip pembangunan berkelanjutan dengan kesetaraan orang, keuntungan, dan planet. Tanpa pembangunan berkelanjutan, pariwisata pasti akan gagal mencapai tujuan otentik pengembangannya.

Pariwisata tidak dikembangkan secara ekologis [11]. Pengembangan pariwisata tidak selalu berhasil walaupun dikembangkan dalam model ekowisata [11]. Namun terkadang gagal mencapai tujuan pembangunan yang otentik karena juga menimbulkan banyak dampak negatif seperti; timbulan limbah padat, gangguan habitat, dan degradasi hutan yang disebabkan oleh erosi jalur. Oleh karena itu, pariwisata mungkin tidak terlalu berkembang dan banyak wisatawan tidak boleh mengunjungi tujuan kampung terih pada saat yang sama. Selain itu terkadang gagal memberikan manfaat ekonomi sementara masyarakat setempat tidak secara langsung menerima keuntungan yang dihasilkan dari pengembangan.

Lebih lanjut, Perserikatan Bangsa-bangsa menyebutkan bahwa pengembangan pariwisata harus didasarkan pada pedoman prinsip-prinsip pariwisata berkelanjutan dan wisata kampung terih diidentifikasi sebagai model pengembangan pariwisata yang didasarkan pada lingkungan, alam, 
dan keanekaragaman hayati. Wwisatawan internasional khususnya wisatawan yang berpendidikan lebih suka mengunjungi destinasi yang sangat memperhatikan kelestarian lingkungan dan konservasi alam dibandingkan destinasi yang melayani perkembangan modern [17].

Dalam studi ini, penelitian ini difokuskan pada perilaku wisatawan dan masyarakat lokal pada permintaan pengembangan kampung terihwisata. Studi ini bertujuan merumuskan model terbaik untuk mengembangkan wisata kampung terih di Batam.

Kampung Wisata Terih merupakan kampung melayu yang berada di Kota Batam [15]. Peruntukan pariwisata dan telah dikembangkan dengan konsep ekowisata. Kampung ini memiliki keindahan alam dan mangrove yang berada di sepanjang garis pantai. Selain itu, kampung ini juga memiliki budaya melayu namun kurang dikembangkan. Kuantitas dan kualitas fasilitas pendukung pariwisata juga kurang baik untuk memenuhi kebutuhan wisatawan. Terlihat lingkungan yang kurang dijaga kebersihannya. Dengan adanya kondisi tersebut, diperlukan adanya penataan dengan konsep ekowisata untuk mewujudkan pariwisata yang berkelanjutan di Kampung Wisata Terih. Metode gap analysis digunakan untuk mengukur kondisi ideal dengan kondisi eksisting di Kampung Terih. Unit analisis yang didgunakan berupa hasil elaborasi dari aspek keruangan, kepariwisataan, ekowisata dan pariwisata berkelanjutan yaitu zona wisata, bangunan, aksesibilitas, atraksi dan aktivitas, partisipasi masyarakat, penanda dan informasi serta preservasi. Pemilihan alternatif rencana dilakukan dengan menggunakan metode performance matrix. Konsep ekowisata digunakan untuk mewujudkan dan memperhatikannya. Adapun 4 prinsip yang digunakan adalah ecological, cultural, educational dan locally participatory. Terdapat 2 alternatif rencana, yaitu centralized yang mengarahkan pembangunan memusat di dekat jalan utama dan distributed yang mengarahkan pembangunan tersebar di seluruh kawasan menjauh dari jalan utama. Alternatif yang terpilih adalah centralized yang kemudian dilanjutkan dengan rencana detil.

Kegiatan pariwisata yang terdiri dari komunitas yang berbasis komunitas, yang terdiri dari sekelompok komunitas yang tidak relevan dengan kegiatan pariwisata, juga di tempat lain. Dengan membangun kepariwisataan, sekelompook komunitas lokal telah menjadi salah satu kesepakatan dan komitmen yang harus tetapkan untuk mendukung pengembangan pariwisata, serta mendukung terwujudnya kualitas sumber daya lingkungan (kualitas sumber daya), kualitas pengalaman wisata (kualitas kepuasan pengunjung), dan juga kualitas Kehidupan masyarakat lokal (kualitas masyarakat setempat) [12]].

Pariwisata merupakan aktivitas, dan penyediaan layanan bagi kebutuhan para wisata, transportasi umum yang digunakan untuk memenuhi kebutuhan perjalanan seseorang atau sekelompok orang. Perjalanan yang dilakukan hanya waktu yang singkat dan bertujuan untuk memenuhi kebutuhannya selama berada di luar tempat tinggalnya [18].

Daya tarik wisata adalah nilai utama penggerak pariwisata di sebuah tempat. Dengan kata lain daya tarik wisata sebagai penggerak utama yang memotivasi wisatawan untuk mengunjungi suatu tempat ketempat yang belum pernah dilihat [8]. Daya tarik wisata tersebut yang terdiri dari wisata rekreasi, wisata kampung terih, wisata hutan bakau, wisata budaya, wisata alam, wisata kuliner dan wisata religi yang merupakan indikator yang bernilai sangat bagus dalam membentuk kebutuhan konsumen. Hal ini dapat simpulkan bahwa daya tarik wisata sebagai pembentuk kualitas layanan, mampu memberikan kepuasan yang tinggi pada pengunjung dan dapat menambah nilai tarik tarik pada obyek wisata tersebut merupakan objek wisata yang paling bagus dalam pikiran para pengunjung [10].

Pariwisata dapat dijelaskan sebagai keseluruhan keinginan seseorang yang berkaitan dengan tinggalnya orang asing disuatu tempat, dengan syarat bahwa mereka tidak tinggal disitu untuk melakukan suatu pekerjaan yang penting yang memberikan keuntungan yang bersifat permanen maupun sementara, serta dapat menikmati ketenangan dalam kehidupannya.

Beberapa prinsip dalam penerapan pariwisata untuk mengunjungi wisatawan yang berdampak pada mereka dalam sebuah tempat pariwisata yang sangat potensial [6].

Pariwisata adalah suatu proses kepergian sementara dari seseorang atau lebih menuju tempat lain diluar tempat tinggalnya, dorongan kepergiannya adalah karena berbagai kepentingan, baik karena kepentingan ekonomi, maupun kepentingan bersama seperti karena sekedar menambah pengalaman ataupun belajar melatih fisik dan mengunjungi tempat baru. Sehingga dalam melakukan perjalanannya tersebut hanya mencari tempat yang sesuai dengan keinginannya serta kebutuhannya agar mendapatkan kepuasan 
yang akan ditemukannya sesuai keinginannya untuk berkunjung kesuatu tempat tersebut [19].

Peningkatan para wisatawan yang terdiri dari pengembangan pariwisata yang berkaitan dengan pendekatan perencanaan pariwisata, yaitu: dukungan wisata yang mencakup wisata alam, budaya, dan lainnya, akomodasi berupa hotel dan jenis fasilitas lainnya yang berhubungan dengan pelayanan terhadap para pengunjung yang menginap agar memudahkan bagi para pengunjung yang berada diluar kota atau wilayah dan pelayanan wisata lainnya yang berhubungan dengan kegiatan pariwisata untuk layanan tranportasi yang mencakup transportasi darat, laut, dan udara, infrastruktur lainnya seperti penyediaan air bersih, tenaga listrik, telekomunikasi, dan lainlain. Elemen institusi yang terkait dengan peningkatan pariwisata, elemen ini penting untuk mengatur dan merencanakan program-program yang dapat meningkatkan daya kunjung pariwisata agar bertambah dari hari ke hari pada setiap wisatawan yang mendatangi desa kampung terih tersebut [7].

Kota Batam terletak dilokasi yang sangat strategis, dan menjadi pusat bisnis yang sangat besar, menjadikan kota tersebut sangat berkembang dari tahun ke tahun. Karena setiap tahun banyak para wisatawan berkunjung ke desa kampung terih karena dengan keindahan alamnya yang sangat memukau dapat meningkatkan daya kunjung wisatawan.

Pariwisata ialah kumpulan setiap organisasi, baik pemerintah maupun swasta yang terkait dalam pengembangan dengan suatu layanan yang memenuhi kebutuhan dari orang yang sedang bepergian dari negara asal dengan tujuan ingin berkunjung kenegara lain [9]. Jadi, secara umum pariwisata merupakan suatu perjalanan yang dilakukan oleh seseorang maupun sekelompok orang dalam waktu tertentu (singkat dan sementara) yang dilakukan dari suatu tempat ke tempat lain dengan suatu perencanaan yang tujuannya sematamata untuk memperoleh kesenangan dan menikmati keindahan alam pada suatu tempat yang dikunjunginya.

Desa kampung terih yang merupakan salah satu tempat objek wisata alam dan dapat membangun dengan memanfaatkan potensi yang ada pada masyarakat demi mensejahterakan kualitas hidup dalam masyarakat pantai terih. Pariwisata berkelanjutan, terlihat bahwa pariwisata berbasis masyarakat fokus pada dampak sosial-budaya, dan melakukan prinsip-prinsip tersebut diantaranya: mengenali tempat wisatawan tersebut serta mendukung dan mempromosikan kepemilikan masyarakat terhadap pariwisata untuk melibatkan anggota masyarakat dari awal dalam semua aspek, menggalakkan kebanggaan masyarakat, meningkatkan kualitas hidup, menjamin kelestarian lingkungan dan keindahan alamnya, mempertahankan karakter unik dan budaya daerah setempat, pembelajaran lintas budaya masyarakat desa kampung terih yang berada tepatnya di kota Batam untuk menghormati budaya dan menghargai martabat masyarakatnya agar bermanfaat secara merata di antara anggota masyarakat yang berada di desa Kampung Terih Kota Batam [20].

\section{METODE}

Penelitian ini merupakan penelitian studi kasus sebagai studi tentang fenomena yang dicontohkan dan diteliti yang bertujuan untuk memahami fenomena dengan jelas dengan memeriksa contoh yang tepat. Studi kasus penelitian ini akan difokuskan di kota Batam karena saat ini digunakan sebagai ikon pariwisata di Indonesia. Batam memiliki desa-desa yang telah dikembangkan dalam bentuk pariwisata kampung terih. Penelitian ini menggunakan observasi langsung, dengan mengamati daerah kampung terih di Batam khususnya daerah yang dijadikan studi kasus [13], yaitu:

a. Jelajah bakau/ 35.000 per orang 45 menitminimal 4 orang

b. Paintball $/ 100.000 / 50$ peluru/minimal 6 orang. A. Instrumen Penelitian

Wawancara

Wawancara termasuk bagian dari instrumen untuk mencari tahu informasi melalui wawancara yang dilaksanakan peneliti di desa kampung terih. Dokumentasi

Dokumentasi merupakan sebuah dokumen yang di dapatkan oleh peneliti yang teridiri dari hasil potret yang diambil dengan kamera dan jenis data lainnya.

\section{B. Teknik Analisis data}

Data dianalisis dengan Structured Equation Modeling (AMOS) dan Microsoft excel. 


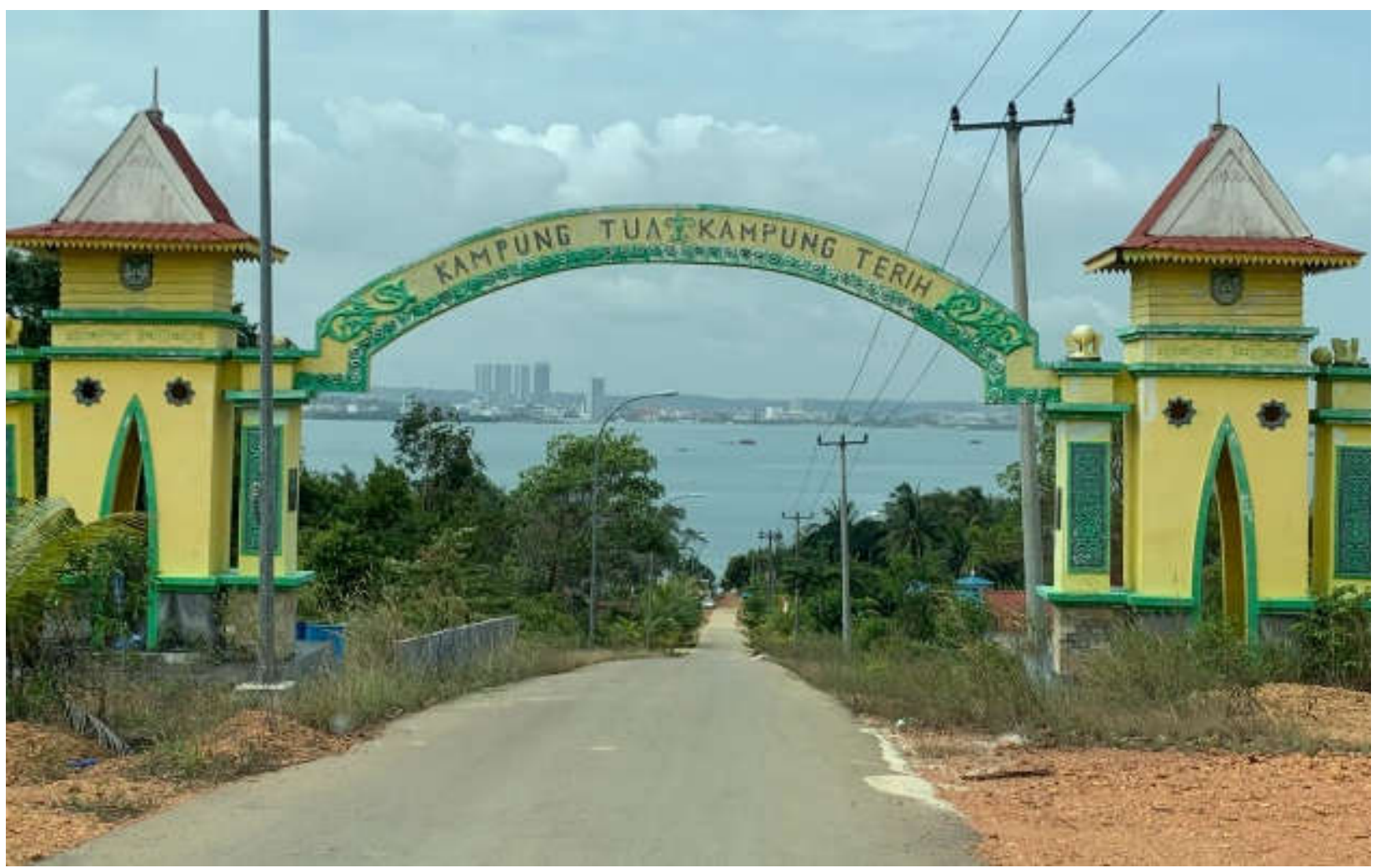

Gambar 1. Gerbang Masuk Kampung Terih

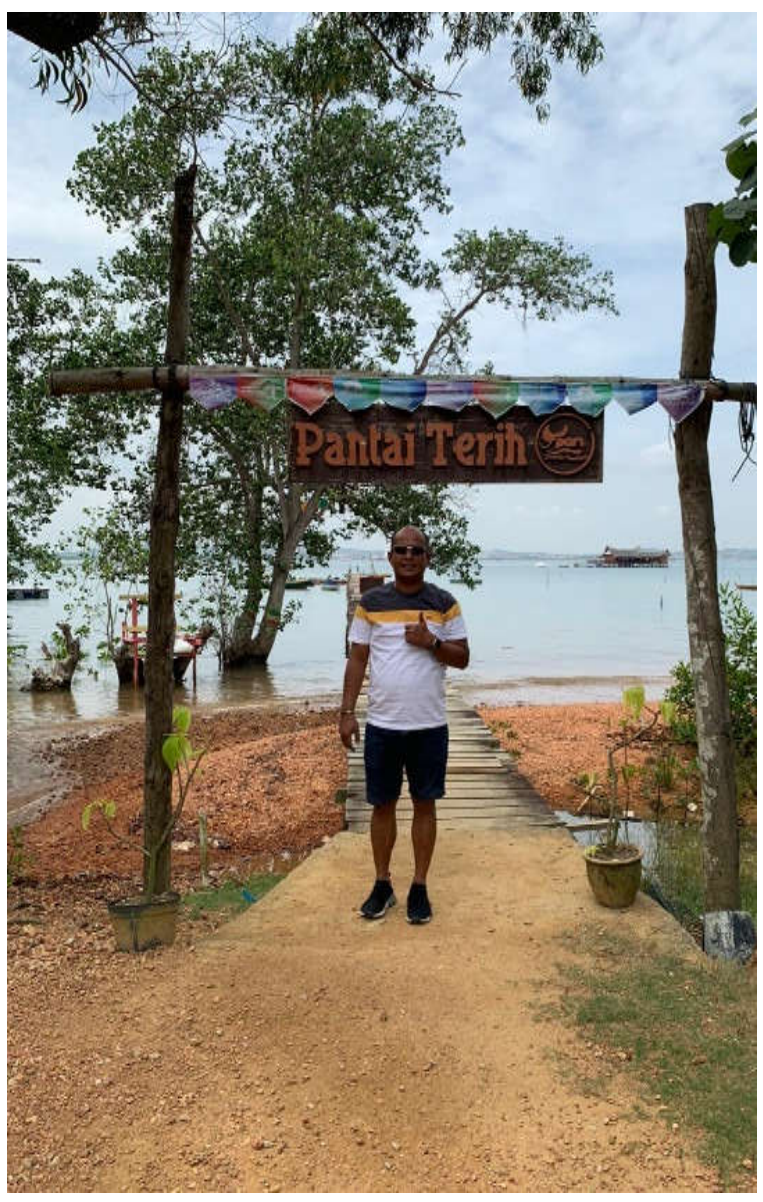

Gambar 2. Pantai Terih

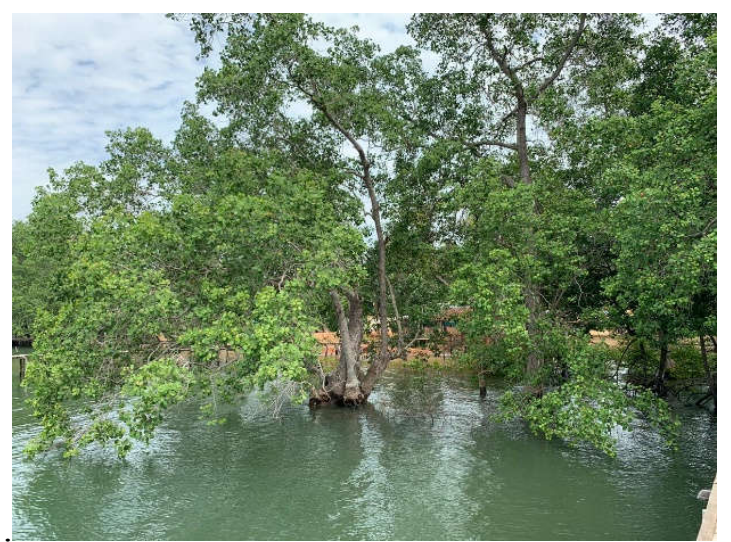

Gambar 3. Hutan Bakau Kampung Terih

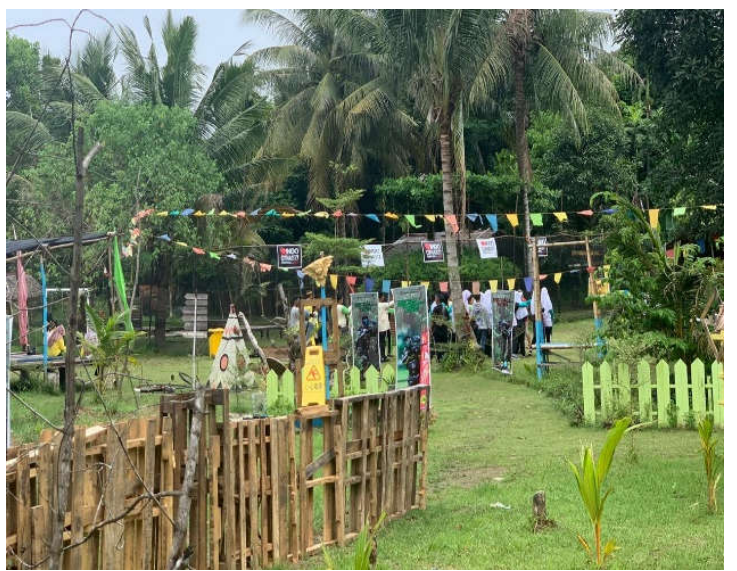

Gambar 4. Paintball, Berkemah, dan Outbond 


\section{Pesona Kampung Terih}

Pesona kampung terih sangat indah dan sangat menarik bagi para wisatawan yang berkunjung kekampung terih, yang berlokasi di kota Batam, kampung terih disebut sebagai Kampung Tua, karena memang masyarakat Kampung Terih sudah ada sejak sebelum Tahun 1991 silam. Namun, dijadikan sebuah lokasi wisata pada Tahun 2017 sampai sekarang oleh para penggiat pariwisata di desa kampung terih.

Gerbang masuk kampung terih (Gambar 1) yang terletak di kawasan kampung tua sebelum menuju desa kampung terih, perjalanan menuju kesana cukup ramai dan dapat manarik daya tarik pengunjung desa kampung terih.

Pantai Terih (Gambar 2) merupakan wisata yang sangat indah dan bagus dengan keindahan alamnya dan pemandangan yang memukau serta para pengunjung pantai terih dapat menikmati keindahan alam di pantai terih, dan dapat melakukan aktivitas seperti olah raga dan beristirahat sambil melepas penat di pantai terih.

Salah satu fasilitas yang paling terkenal adalah Sea Forest / Hutan Bakau (Gambar 3). Kawasan Sea Forest memiliki luas sekitar 1800 meter persegi. Di dalam Sea Forest, menawarkan berbagai aktivitas. Seperti paint ball, berkemah, hingga outbond. (Gambar 4)

\section{HASIL DAN PEMBAHASAN}

\section{A. Pesona Kampung Terih}

Pesona Kampung Terih saat ini juga telah menjadi tempat wisata yang mudah diakses di internet, dan lokasinya mudah di jumpai ketika kita berkunjung ke kota Batam. Fasilitas yang dinikmati pengunjung di Kampung Terih, seperti hutan bakau, pondok-pondok tempat berteduh, tempat berkemah. Aktivitas rekreasi juga bisa menjadi pilihan yang menarik untuk melepas penat di Kampung Terih. Jika pengunjung ingin menjelajah hutan bakau, siapkan perahu tradisional yang bisa dipakai untuk bepergian bagi wisatawan yang ingin mengelilingi wilayah desa kampung terih.

\section{B. Pengembangan Desa Pariwisata untuk Mengunjungi Kampung Terih \\ Pengunjung Kampung Terih motivasi yang kuat untuk mendorong wisatawan mengunjungi kampung terih adalah melatih fisik, memperkaya kecerdasan, istirahat dan relaksasi, menjauhkan diri dari stress, terlihat pada tabel 1 .}

Tabel 1. Pengembangan Desa Pariwisata untuk Mengunjungi Kampung Terih

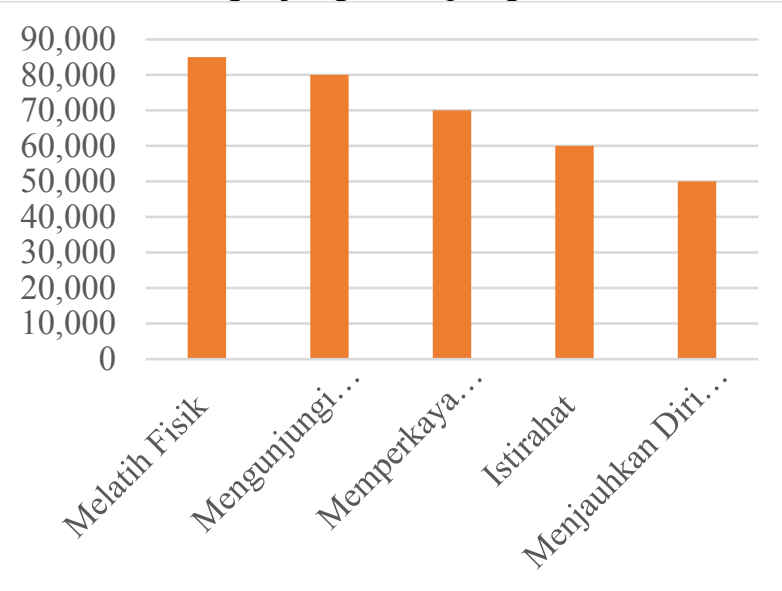

Sumber: Grafik Pengembangan Desa Pariwisata Untuk Mengunjungi Kampung Terih

Opini Responden tentang melatih fisik 85.000 Sangat Kuat, Mengunjungi tempat baru 80.000 kuat, Memperkaya kecerdasan 70.000 Kuat, Istirahat 60.000 Sedang, Menjauhkan diri dari stres 50.000 lemah,

Tabel 2. Pariwisata Untuk Mengunjungi Kampung Terih

\begin{tabular}{|c|l|c|c|}
\hline No & \multicolumn{1}{|c|}{ Indicator } & Mean & Meaning \\
\hline 1 & $\begin{array}{l}\text { Kekayaan kuliner } \\
\text { khas Melayu dari } \\
\text { warganya }\end{array}$ & 80.000 & Kuat \\
\hline 2 & $\begin{array}{l}\text { Spot-spot foto } \\
\text { yang } \\
\text { instagramable }\end{array}$ & 75.000 & Sedang \\
\hline 3 & $\begin{array}{l}\text { Pondok Tempat } \\
\text { Bersantai } \\
\text { Pengunjung }\end{array}$ & 60.000 & Sedang \\
\hline 4 & Perkemahan & 55.000 & Lemah \\
\hline
\end{tabular}

Sumber: Tabel Pariwisata Untuk Mengunjungi Kampung Terih

\section{Pariwisata untuk Mengunjungi Kampung Terih}

Wisatawan untuk mengunjungi kampung terih adalah kekayaan kuliner khas Melayu dari warganya, Spot-spot foto yang instagramable, pondok tempat bersantai pengunjung dan perkemahan, terlihat pada tabel 2 .

Opini Responden tentang kekayaan kuliner khas Melayu dari warganya 80.000 Sedang, Spotspot foto yang Instagramable 75.000 sedang, pondok tempat bersantai pengunjung 60.000 sedang dan perkemahan 55.000 lemah. 


\section{Keberlanjutan Kampung Terih}

Keberlanjutan pariwisata kampung terih tergantung pada loyalitas wisatawan kampung terih terlihat dari kemauan untuk merekomendasikan teman atau keluarga, dan keinginan untuk kembali. Keberlanjutan desa wisata kampung terih juga membutuhkan dukungan pemerintah dan dukungan dari masyarakat setempat yang saat ini masih termasuk lemah karena hanya beberapa penduduk desa yang terlibat dalam desa wisata tersebut. Selanjutnya, operasionalisasi variabel keberlanjutan agrowisata diterjemahkan menjadi empat indikator yang terdiri

Tabel 3. Keberlanjutan Kampung Terih

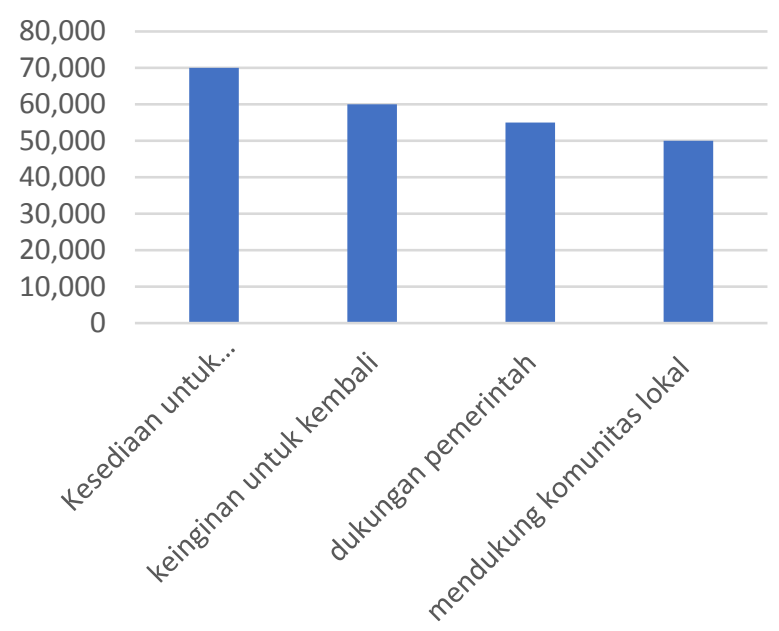

Sumber: Grafik Keberlanjutan Kampung Terih Pendapat Responden tentang Faktor Keberlanjutan

Kesediaan untuk merekomendasikan teman atau keluarga, 70.000 sedang, keinginan untuk kembali 60.000 sedang, dukungan pemerintah 55.000 sedang, mendukung komunitas lokal 50.000 Lemah.

\section{KESIMPULAN}

Berdasarkan tujuan penelitian ini kesimpulan dan rekomendasi model objek wisata yang diharapkan oleh rating wisata kampung terih adalah. Pada fasilitas, wisatawan mengharapkan fasilitas yang meliputi, antara lain: motivasi yang kuat untuk mendorong wisatawan mengunjungi kampung terih adalah melatih fisik, memperkaya kecerdasan, istirahat dan relaksasi, menjauhkan diri dari stres. Pada aksesibilitas, para wisatawan menganggap bahwa jarak perjalanan Kampung terih cukup jauh, dan sulit dijangkau dengan transportasi umum. Selain jarak yang cukup jauh, para jalur yang harus dilalui ke kampung terih juga termasuk jalur sibuk dan sering macet. Hasil penelitian yang telah dilakukan menunjukkan bahwa kampung terih telah dikelola dengan baik yang terbukti dari keterlibatan masyarakat setempat (komunitas pariwisata), layanan panduan (link agen perjalanan) layanan pemandu lokal (komite pariwisata), dan dukungan pemerintah (pemegang lisensi Walikota). Solusi yang jarak dari ibu kota dapat diatasi dengan membuat paket perjalanan khusus yang memungkinkan wisatawan dapat tinggal di Kampung terih, dan dikombinasikan dengan paket wisata lingkungan, terutama ekowisata ke kampung terih di Batam.

\section{DAFtar Pustaka}

[1] Agenda 21. (2006) Industri Pariwisata Perjalanan; menuju Pembangunan Berkelanjutan yang Ramah Lingkungan, WTTC, WTO, Dewan Bumi.Annals of Tourism Research.

[2] Asman Abnur (2019). Analisis Strategi Pengembangan Masyarakat Kampung Terih, Nongsa, Kota Batam,Kepulauan Riau Sebagai Salah Bentuk Pengembangan Potensi Pariwisata Berkelanjutan.Riau: Politeknik Pariwisata Batam

[3] Batam.tribunews.com. (2018, 1 November).Hebat, Wisata Kampung Terih Batam Raih Predikat Destinasi Wisata Baru Terpopuler di Indonesia. Diakses pada 10 Desember 2019, dari

https://batam.tribunnews.com/2018/11/01/hebatwisata-kampung-terih-batam-raih-predikatdestinasi-wisata-baru-terpopuler-di-indonesia.

[4] Batam.tribunews.com. (2019, 9 Januari). Tempat Wisata Batam - Kampung Terih Nongsa, Kampung Wisata Kekinian. Diakses pada 10 Desember 2019, dari https://batam.tribunnews.com/2019/0

1/19/teampat-wisata-batam-kampungterihnongsa-kampung-wisatakekinian-di-batam

[5] Batamnews co.id. (2018, 24 November).Pengelola Kampung Terih: Tak Ada Andil, Pemko Batam Hanya Bisa Ambil Piala. Diakses pada 10.

[6] Drake; Wayne Vogl; Adam W M Mitchell. Gajah Mada University Press; 1991: P. 1-40; 194-244. 23.

[7] Inskeep, Edward. 1991. Tourism Planning: An Integrated and Sustaniable Development Approach. New York : Van Nostrand Reinhold.

[8] Ismayanti. (2009). Pengantar Pariwisata. Jakarta: Grasindo.

[9] Kusdianto Hadinoto. 1996. Perencanaan Pengembangan Destinasi Pariwisata. Jakarta : UI Press.

[10] Martaleni. (2011). Pertumbuhan Pariwisata Global: Tantangan untuk Pemasaran.

[11] McIntosh dan Goeldner. (1990). Pariwisata. Prinsip, Praktik, dan Filsafat (edisi keenam), Grid Publishing, Columbus. 
[12] Murphy, Peter. E. 1998. Tourism: A Community Approach. London : Methven.

[13] Pujaastawa. 2005. Pariwisata Terpadu. (Alternatif. Model.

[14] Putri dkk. 2018. Strategi Pengembangan Potensi Desa Wisata Berbasis Analisis SWOT desa Sidomekar dan Penggunaan Aplikasi Tour Guide Online Kabupaten Jember. Proceeding Seminar Nasional Manajemen dan Bisnis ke-3 Program Studi

[15] Stephanie audry anita putri, ratna eka suminar, st., m.sc. Universitas gadjah mada, 2018 | diunduh dari http://etd.repository.ugm.ac.id/

[16] Subadra, I Nengah. Pembangunan Pariwisata Berkelanjutan, 2006.

[17] Sudibyo. 2002 . Perilaku Konsumen dan Kesinambungan Kebutuhan. Jakarta.

[18] Sugiama 2011, Manajemen Aset Pariwisata, Bandung : Guardaya Intimarta

[19] Suwantoro, Gamal. 2004. Dasar-dasar Pariwisata. Penerbit Andi Yogyakarta.
[20] World Tourism Organization. 2000. WTO News Issue 2. Madrid.

\section{Biodata Penulis}

Syafruddin Rais, bekerja di Politeknik Pariwisata Batam, lahir di Kabupaten Agam pada tanggal 27 Oktober 1975. Menyelesaikan Program D4 Pariwisata di Fakultas Pariwisata Universitas Udayana Bali pada Tahun 2001. Lulus dengan Gelas Magister Pariwisata (M.Par) dari Universitas Udayana Bali pada tahun 2011. Saat ini sedang menempuh pendidikan S3 Pendidikan Teknologi Kejuruan di Universitas Negri Padang. 